\title{
Tokoh agama dalam penyebaran hoax di whatsapp group (ditinjau dengan teori dominasi Max Weber)
}

\author{
Atma Mubarok, Ahmad Arif Widianto* \\ Universitas Negeri Malang, Jl. Semarang No. 5 Malang, Jawa Timur, Indonesia \\ *Penulis korespondensi, Surel: ahmad.arif.fis@um.ac.id
}

Paper received: 03-02-2021; revised: 15-02-2021; accepted: 28-02-2021

\begin{abstract}
Abstrak
Saat ini, media sosial semakin masif penggunaanya di dunia atau bahkan di Indonesia. Sayangnya, peningkatan penggunaan internet dan media sosial juga diiringi dengan kenaikan penyebaran hoax di media sosial. Salah satu media sosial yang paling sering dijadikan penyebaran informasi hoax adalah WhatsApp group. Sehingga setiap pengguna dapat langsung mengirimkan pesan yang diterima tanpa melakukan crosschek terlebih dahulu. Lebih parah, tokoh agama ikut menjadi penyumbang kenaikan angka penyebaran informasi hoax. Seorang tokoh agama layaknya pemimpin bagi umatnya, sehingga apapun yang dilakukan oleh pemimpinnya, sedikit banyak akan mempengaruhi masyarakat yang ada. Dalam masyarakat desa, seorang tokoh agama dianggap suci dan sangat dihormati termasuk semua anggota keluarganya. Max Weber menjelaskan beberapa konsep mengenai kepemimpinan yang diuraikan dalam teori dominasi. Diantaranya adalah kepemimpinan tradisional dan karismatik yang kerap dijumpai di masyarakat pedesaan. Tanggung jawab untuk menjadi contoh dan panutan bagi sekitar mereka, menuntut mereka untuk selalu berusaha berperilaku sesusai norma. Sayangnya, hal itu belum bisa diimbangi dengan kemampuan mencerna informasi dari media sosial.
\end{abstract}

Kata kunci: tokoh agama; hoax; media sosial.

\section{Pendahuluan}

Saat ini, media sosial semakin masif penggunaanya di dunia atau bahkan di Indonesia. Informasai yang kami dapat dari halaman kominfo.go.id menunjukkan bahwa Kementerian Komunikasi dan Informatika (Kemenkominfo) mengungkapkan pengguna internet di Indonesia saat ini mencapai 63 juta orang. Dari angka tersebut, 95 persennya menggunakan internet untuk mengakses jejaring sosial. Namun dari info terbaru dari laman kominfo, terdapat peningkatan penggunaan internet selama pandemi. Sebelumnya trafik penggunaan internet sebagian besar berada di area kampus atau perkantoran, kini berpindah ke rumahrumah warga. Kominfo juga memperkirakan akan terjadi peningkatan sebesar $40 \%$ selama pandemi ini. Salah satu media sosial yang saat ini paling banyak digunakan adalah WhatsApp. Aplikasi yang diluncurkan pertama pada tahun 2009 itu semakin menarik perhatian setelah pada 2014 diakuisisi oleh Facebook.inc. Data yang kami peroleh dari liputan6.com, sebesar 83\% pengguna internet di Indonesia menggunakan aplikasi WhatsApp. Atau apabila dikalkulasi menggunakan angka, sekitar 143 juta masyarakat Indonesia menggunakan aplikasi WhatsApp.

Sayangnya, peningkatan penggunaan internet dan media sosial juga diiringi dengan kenaikan penyebaran hoax di media sosial. Data dari Kominfo.go.id yang sudah melakukan pemantauan sejak 2016 mengenai berita hoax yang disebar di internet dan pada tahun tersebut terdapat 14 laporan berita hoax yang berisi separatisme dan organisasi berbahaya. Selanjutnya di tahun 2017 angkanya meningkat menjadi 281 laporan dan pada tahun 2018 ada sekitar 1.440 laporan berita negatif. Dari sekian banyak data tentang penyebaran berita hoax, 
cukup tragis bahwa orang dengan usia lebih dewasa lah yang paling banyak menyebarkan berita hoax. Data yang kami dapat dari sebuah artikel di Tirto.id menyebutkan hasil penelitian yang dilakukan New York University dan Pricenton University pada tahun 2016 terhadap pengguna Facebook di Amerika bahwa, warga dengan usia 65 tahun atau lebih memiliki andil besar dalam kasus penyebaran hoax sebesar 11\%. Sementara pada usia 18-29 tahun hanya 3\% saja yang melakukan penyebaran berita hoax. Menurut Ketua Masyarkat Anti Fitnah Indonesia (MAFINDO), generasi dengan usia diatas 40 tahun atau yang lahir sekitar tahun 1960 an tumbuh di era media disebarkan secara redaksional. Sehingga ketika mereka mulai mengenal era digital dimana semua orang dapat menjadi produsen berita, mereka lantas percaya bahwa setiap berita yang ditulis adalah berita yang kredibel.

Salah satu fenomena yang akan diangkat adalah kasus penyebaran hoax yang dilakukan seorang tokoh agama yang sekaligus menjadi tokoh masyarakat di group WhatsApp RT Desa Njari Kecamatan Talun Kabupaten Blitar. Saat awal diterapkan PSBB di Indonesia, salah satu kebijakan yang diterapkan adalah sekolah dimulai dari rumah. Kami melansir dari Kompas.com, mendikbud Nadiem Makarim menggandeng TVRI sebagai inisiator proram tersebut. Salah satu alasan kenapa kebijakan tersebut dibuat adalah untuk memberikan solusi pada peserta didik yang tidak bisa mendapatkan akses internet yang stabil apabila pembelajaran dilakukan secara online. Ketika dimulai pada tanggal 13 April kemarin, berita hoax mengenai program tersebut sudah menyebar dengan cepat khususnya di group WhatsApp. Yaitu berupa satu video yang menunjukkan anak kecil dengan pakaian islami sedang membacakan puisi bertema pluralisme Indonesia dimana di caption video tersebut mengatakan bahwa video tersebut merupakan tayangan dari TVRI pada tanggal 13 April. Semakin cepat menyebar karena disertai caption khas berita hoax yang konfrontatif. Kami kutip sedikit caption yang dilampirkan di video tersebut, "Pertanyaannya, apakah murid SD seIndonesia Bersama para orang tuanya se-Indonesia itu disengaja untuk dicekoki mimbar katolik? Astaghfirullah al'adhim". Pihak TVRI membantah isu tersebut dan melakukan pengecekan ulang dan tidak menemukan video tersebut disiarkan di TVRI. Melalui wartaekonomi.co.id Komisi Penyiaran Indonesia juga menegaskan bahwa video tersebut tidak pernah tayang di TVRI.

Video tersebut dibagikan oleh seorang yang berpengaruh di lingkungan masyarakat karena merupakan seorang putra dari Kyai di desa. Sehingga berita hoax yang sudah dikirim di group WhatsApp tersebut mendapat respon bermacam-macam. Sayangnya, sebagian besar orang mempercayai bahwa berita tersebut asli, mungkin salah satu faktor yang mempengaruhi adalah pihak yang menyebarkannya. Masyarakat desa sebagai sebagai masyarakat yang tradisional, memang masih sangat menghormati sosok seorang tokoh agama atau tokoh masyarakat lainnya. Dalam hal ini, Kyai dianggap sebagai sosok tokoh yang suci yang dihormati, sehingga anggota keluarga dan kerabat Kyai juga mendapat penghormatan yang sama. Weber menjelaskan, terdapat beberapa model kepemimpinan, salah satunya adalah kepemimpinan tradisional. Hal itu terjadi ketika keturunan dari salah satu pemimpin atau tokoh, sama dihormati dan dijadikan panutan seperti pemimpin sebelumnya. Kemudian model kepemimpinan yang lain adalah kepemimpinan karismatik. Hal ini berarti seorang pemimpin dipilih berdasarkan personanya yang bisa menarik perhatian masa dengan keahliannya. Orang-orang dengan tingkat spiritualitas tinggi dalam masyarakat dianggap sebagai orang yang memiliki keahlian lebih. Sehingga Max Weber sering menyebut sifat kepemimpinan karismatik ini dimiliki oleh mereka yang menjadi pemimpin keagamaan. Selanjutnya, tulisan 
ini akan melihat bagaimana orang-orang dengan kredibilitas tinggi di sebuah lingkungan desa memainkan perannya dalam penyebaran hoax di media sosial.

\section{Metode}

Penelitian ini menggunakan metode penelitian kualitatif dengan pendektan deskriptif. Penelitian kualitatif bertujuan untuk memahami fenomena yang dialami oleh subjek penelitian, misalnya perilaku, persepsi, motivasi, tindakan, dan sebagainya pada kondisi objek ilmiah dan dengan memanfaatkan metode alamiah. Moelong (2004). Metode kualitatif berusaha memahami dan menafsirkan makna suatu peristiwa interaksi tingkah laku manusia dalam situasi tertentu menurut perspektif peneliti sendiri. Penelitian yang menggunakan penelitian kualitatif bertujuan untuk memahami obyek yang diteliti secara mendalam yaitu bagaimana peran seorang tokoh agama dalam menyikapi berita hoax.

Tahap pertama peneliti melakukan observasi pada objek penelitian yaitu lingkungan RT khususnya dalam group WhatsApp.. Menurut Arikunto (2003), observasi merupakan pengumpulan data dengan melakukan pengamatan secara langsung terhadap objek yang akan diteliti. Observasi dilakukan untuk melihat respon pengguna WhatsApp yang tergabung dalam group WhatsApp tersebut pada berita hoax yang dibagikan.

Peneliti juga akan menggunakan sumber data sekunder sebagai informasi tambahan dari jurnal, artikel atau media inforasi lainnya. Menurut Creswell dalam Habsy (2017), studi literatur merupakan rangkuman dari berbagai jurnal, buku atau dokumen lain yang menjelaskan konsep atau teori yang sesuai dengan topik atau dokumen yang diperlukan. Sumber data sekunder juga kami perlukan, mengingat saat ini masih dalam kondisi pandemi sehingga mobilitas sangat terbatas.

Studi dokumentasi adalah teknik dalam pengumpulan data dengan pengumpulan dokumen yang diperlukan dan berhubungan dengan masalah yang sedang diteliti untuk ditinjau secara mendalam sehingga dapat mendukung pembuktian suatu problema. Iskandar, 2009 (dalam Saputri, 2018). Dalam hal ini, peneliti meninjau media WhatsApp Group untuk mendapat data berupa tangkapan layar percakapan yang dilakukan antara tokoh agama yang menyebarkan hoax dan respon beberapa anggota WhatsApp Group.

\section{Hasil dan Pembahasan}

Berdasakan hasil observasi yang dilakukan pada media WhatsApp gorup RT, didapat data berupa gambar percakapan antara tokoh agama yang mengirimkan pesan hoax dan respon dari beberapa anggota group lainnya. Peneliti melihat perbedaan respon antara anggota group dengan usia mudia yaitu dengan usia sekitar 20 tahun dan respon dari anggota group dengan usia dewasa yaitu 40 tahun.

Gambar di bawah merupakan potongan pesan hoax yang dikirimkan, dengan isi dalam pesan tersebut adalah penjelasan mengenai waktu penayangan dan beberapa informasi mengenai isi video yang disebut sebagai mimbar Katolik. Pesan tersebut dimulai dengan narasi yang cukup konfrontatif yaitu "proses belajar online yang dapat menyimpang dari aqidah". Pesan tersebut dibuat seolah-olah pihak kemendikbud bertanggung jawab dengan sengaja menayangkan konten mimbar Katolik di televisi nasional pada jam pelaksanaan pembelajaran. 


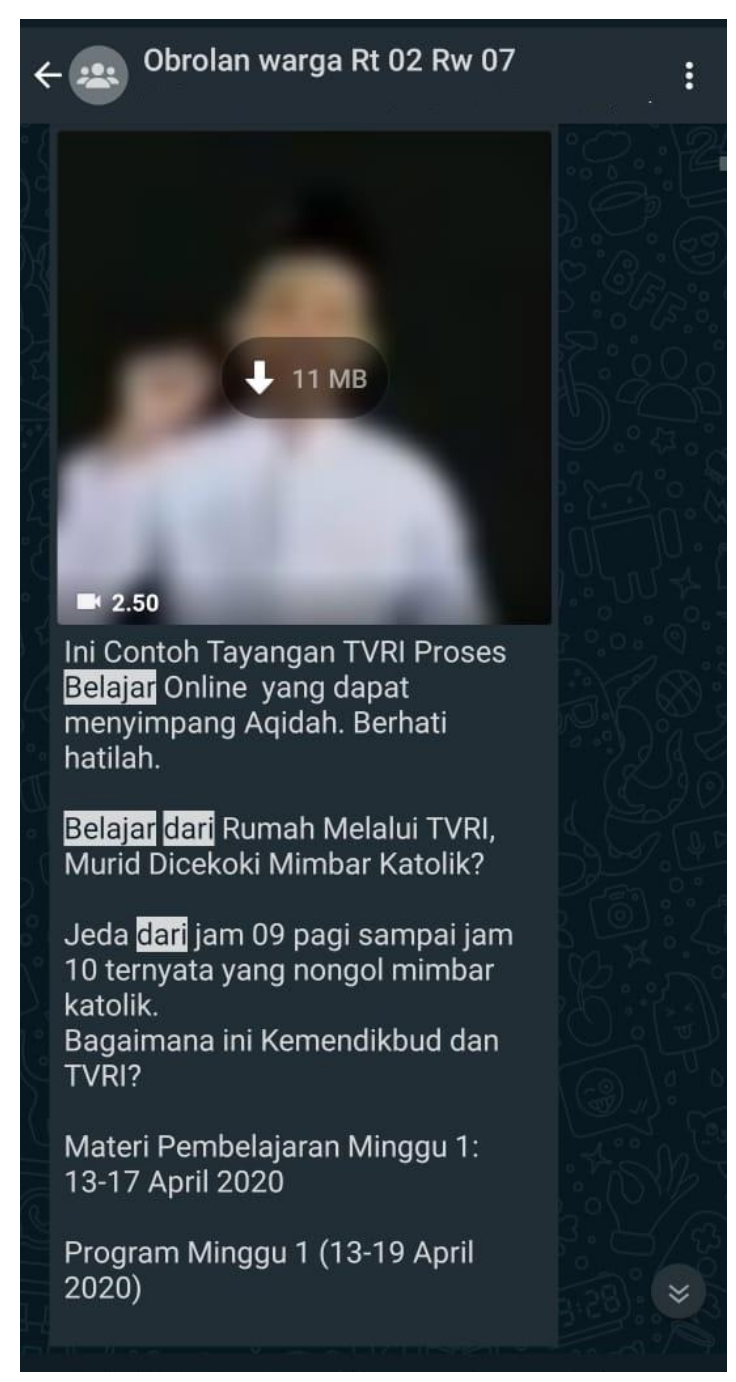

Gambar 1. Contoh pesan hoax yang ditayangkan

Kemudian terdapat gambar kedua yang berisi caption dari pesan tersebut yang berisikan keberatan mengenai adanya video tersebut apabila muncul pada saat jam pembelajaran siswa SD. Pada pesan tersebut juga dituliskan apakah memang pihak dari pemerintah sengaja menampilan konten mimbar Katolik tersebut dengan tujuan memberikan video tersebut. Kemudian juga penulis pesan menyampaikan keberatannya yaitu mengapa seorang anak kecil dengan atribut agama Islam atau dari organasisai NU menyampaikan narasi seperti mimbar katolik. Pihak yang mengirimkan pesan hoax tersebut menambahkan, bahwa dirinya tidak melihat secara langsung penayangan video tersebut di televisi, dia mendapatkan info tersebut dari beberapa wali murid di pondok pesantren tempat anaknya menempuh pendidikan dan beberapa wali murid sudah melakukan komplain. Setelah pesan tersebut dikirim, terdapat beberapa respon dari anggota yang ada di dalam group tersebut. Salah satu anggota menyarankan untuk seggera melaporkan konten tersebut pada Komisi Penyiaran Melalui web resmi dari KPI. Sedikit informasi, bahwa anggota yang menyarankan untuk melakukan laporan pada pihak KPI berusia sekitar 20 tahun. Kemudian ada pula anggota yang sudah memiliki anak ikut merespon dan menyayangkan bahwa dirinya tidak ikut mendampingi anaknya ketika melakukan proses pembelajaran online melalui media televisi. 


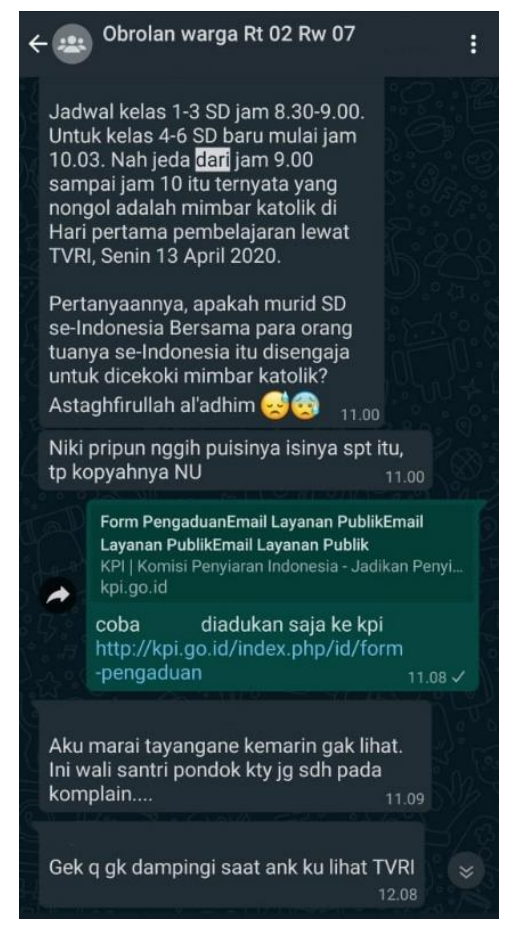

\section{Gambar 2. Caption Obrolan WA tentang Keberatan Adanya Tayangan Tertentu}

Selanjutnya pada gambar ketiga respon bertambah dari salah satu anggota dengan usia 21 tahun memberikan informasi berupa link sebuah berita dari mnctrijaya.com yang berisi mengenai klarifikasi dari pihak TVRI bahwa pesan tersebut adalah hoax. Pihak TVRI tidak pernah menayangkan video tersebut dan dalam laman berita tersebut juga dijelaskan bahwa itu merupakan video yang sudah beredar di media Youtube sejak 2017.

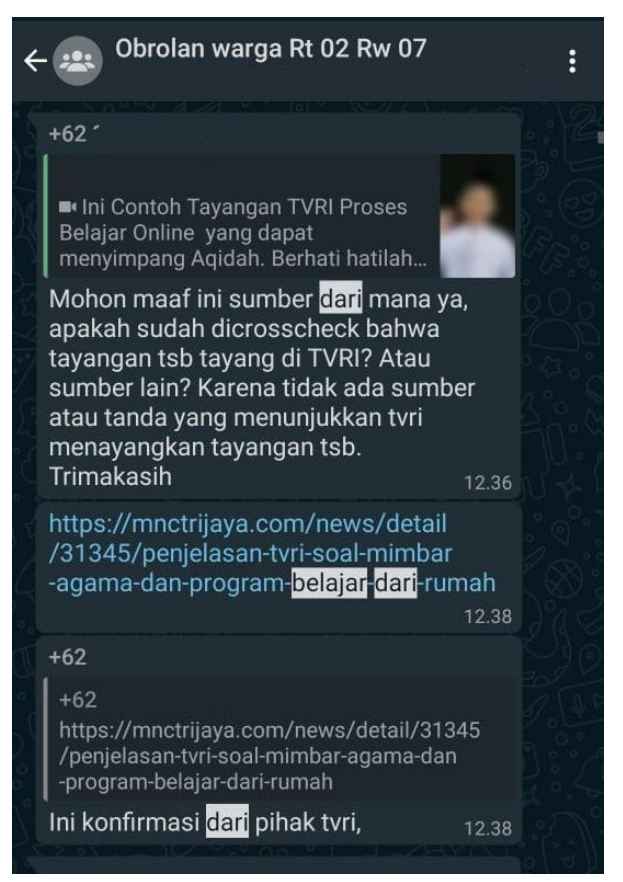

Gambar 3. Respon dari Warga Lainnya 
Kemudian peneliti meninjau isi video tersebut yang secara garis besar berisi pesan untuk menjunjung toleransi. Memang pada video tersebut narasi yang disampaikan mirip dengan mimbar Katolik dengan beberapa kali menyebut kata yang identik dengan agama Katolik seperti Yesus, penebusan dosa, dan palang kayu. Pada video tersebut secara eksplisit memang menyampaikan narasi toleransi, namun secara implisit memang jelas beberapa anak yang memakai atribut Islam menyampaikan sebuah narasi yang biasa disampaikan pada mimbar katolik.

\subsection{Hoax di media sosial}

Sejak media sosial muncul menjadi sebuah fenomena baru, pengguna tidak lagi hanya menjadi konsumen sebuah informasi namun juga produsen. Sebelum era media sosial, penyebaran informasi masih bersifat redaksional sehingga tidak bisa diproduksi dan didistribusikan oleh semua pihak. Setelah munculnya media sosial yang dapat diakses oleh siapa saja yang memiliki perangkat, setiap orang dapat memproduksi sebuah informasi sendiri. Setiap orang bebas menyampaikan argumen dan narasi dan mendapat atensi dari publik tanpa harus melalui kantor redaksi.

Demokrasi di era media sosial begitu terasa di masyarakat karena setiap orang benarbenar mendapatkan hak untuk berbicara dan menyampaikan pendapat di muka umum. Sayangnya kemudahan dalam menyampaikan argumen dan informasi tersebut tidak diimbangi dengan kebijaksanaan penggunanya dalam menyampaikan sebuah informasi. Setiap pihak dapat membuat sebuah informasinya sendiri yang kemudia dengan mudah disebarkan ke publik di media sosial. Tidak semua pihak bertanggung jawab akan sebuah informasi yang mereka tulis, terkadang memang ada spihak yang membuat informasi dengan sengaja menyudutkan, menghina, atau mempersekusi pihak lain. Tindakan offensif tersebut juga dilengkapi dengan data yang telah dimanipulasi dengan tujuan supaya informasi yang disebar terlihat kredibel.

Jemadu (2017) menjelaskan fenomena hoax mulai banyak muncul ketika pemilihan umum, pilkada atau pemilihan presiden. Informasi hoax, pada dasarnya bertujuan menggiring opini seseorang atau kelompok sesuai dengan kehendak pembuat informasi hoax. Menurut Respati (2017), penerimaan berita hoax akan lebih mudah dipercayai apabila ada kesamaan persepsi antara produsen dan konsumen hoax. Sehingga orang akan cenderung mempertahankan opini yang sejalan daengan persepsi mereka, entah itu hoax atau fakta. Dengan semakin mudahnya menyebarkan informasi, cukup sulit untuk melacak pihak pertama yang menyebarkan sebuah informasi hoax. Hal ini diperparah dengan ketidakmauan pengguna media sosial untuk melakukan pengecekan mengenai sumber dan kredibilitas sebuah informasi yang didapat. Biasanya dalam proses distribusi informasi hoax oleh pengguna khususnya di media WhatsApp group dimulai dengan kalimat "Dapat info dari group sebelah" yang dilanjutkan dengan pesan atau informasi yang belum jelas sumber dan kredibilitasnya.

Nasution (2017) menuliskan beberapa hal yang dapat membedakan berita hoax dan fakta, seperti penggunaan kata yang tidak baku, sumber informasi yang tidak jelas, dan informasi yang disampaikan tidak bisa dibuktikan. Namun, masalah muncul ketika orang tua kesulitan membedakan mana informasi hoax dan fakta. Sementara Tutiasri (2019) menjelaskan bahwa orang-orang dewasa atau usia 50 tahun keatas adalah sumber utama atau orang yang paling sering menyebarkan berita hoax di group WhatsApp. Sedangkan mereka 
yang masih berusia remaja, cenderung lebih selektif dalam membagikan sebuah informasi yang mereka terima. Banyak informasi hoax yang melampirkan data yang dimanipulasi untuk membuat informasi tersebut terlihat formal.

Orang-orang tua tumbuh di era sebelum media sosial, sehingga bagi mereka saat ini media sosial merupakan hal baru dan secara psikologis mereka lebih sulit beradaptasi dari pada kalangan muda. Golongan usia tua cenderung lebih mudah menyebarkan dan percaya berita hoax di media sosial dari pada usia muda karena generasi dari golongan tua terlambat dalam menerima dan menggunakan media sosial. Menurut Septiadji yang menjabat Ketua Masyarkat Anti Fitnah Indonesia (MAFINDO), banyak dari golongan tua yang memiliki jabatan dan gelar tinggi seperti doktor, profesor, atau pemuka agama. Tetapi meskipun memiliki berbagai keahlian, golongan tersebut masih kurang dalam kemampuan mencerna sebuah berita di media sosial. Penyebaran hoax diperparah dengan kultur hirarki di Indonesia berdasarkan usia, jabatan atau profesi tertentu. Sehingga mereka yang memiliki usia lebih dewasa dianggap lebih berpengalaman pada segala bidang, dan golongan tua dengan leluasa menyebarkan berita hoax dengan dalih "sekedar berbagi informasi".

\subsection{Teori dominasi Max Weber}

Teori dominasi dari Max Weber menyebutkan bahwa tipe kepemimpinan dibagi menjadi 3, yaitu tradisional, karismatik dan rasional. Turner dalam Arifin (2015) menjelaskan mengenai karakteristik dari beberapa tipe kepemimpinan yang disebutkan Max Weber.

Kepemimpinan tradisional bersumber pada aturan dari tradisi masyarakat setempat yang berlaku. Anggota keluarga atau kerabat dari seorang pemimpin, akan menjadi pemimpin selanjutnya apabila pemimpin yang lama sudah tidak lagi memimpin. Dimana masyarakat akan mematuhi dan menghormati seluruh anggota keluarga dari seorang pemimpin. Karena nantinya apabila kepemimpinan sudah beralih ke anggota keluarga lain, masyarakat akan segera mematuhi peraturan baru yang telah dibuat sebagaimana mereka mematuhi pemimpin yang sebelumnya. Misalnya anak seorang pemimpin agama akan sama dihormatinya seperti orang tuanya.

Kepemimpinan karismatik, berakar dari sebuah karakter yang kuat, dimana karisma tersebut tidak dimiliki oleh orang lain. Hal ini bisa berarti kesucian, kepahlawanan, atau sifatsifat pemimpin ideal lainnya. Karisma pada Seseorang akan muncul berdasarkan tingkat spiritualitasnya (Karim, 2009). Weber juga menamahkan bahwa keahlian yang dimiliki oleh sosok karismatik diartikan sebagai bakat atau pemberian dari Tuhan kepada orang-orang pilihan. Sosok pemimpin dengan tipe karismatik, kerap kali muncul pada saat kondisi krisis dimana dia membawa visi dan tujuan sehingga mendapat atensi dari publik.

Kemudian kepemimpinan rasional, yaitu seorang pemimpin yang diangkat berdasarkan aturan atau prosedur yang sudah ditetapkan. Proses pemilihan pemimpin pada hal ini didasarkan pada sebuah peraturan yang sudah dibuat dan disepakati bersama. Misalnya pada pemilihan Bupati, Gubernur atau pemilihan Presiden yang sudah diatur pada undang-undang.

\subsection{Tokoh agama dan penyebaran hoax}

Indonesia sebagai negara dengan adat ketimuran yang kental, masih memegang teguh prinsip ketokohan. Seseorang yang dihormati dan dianggap sebagai tokoh masyarakat akan 
lebih mudah diterima pendapat atau narasinya karena dianggap sebagai sosok dengan kredibilitas tinggi. Hal itu karena mereka seolah diberi tanggung jawab untuk memberi contoh dalam berperilaku kepada masyarakat. Padahal seorang tokoh masyarakat tidak serta merta menjadi pakar di semua bidang yang ada karena menjadi tokoh masyarakat. Tetapi pada praktiknya, seseorang dengan keahlian tertentu atau lebih khusus di bidang spiritual menempati strata sosial yang tinggi di masyarakat. Dapat dikatakan masyarakat memiliki keyakinan bahwa seseorang dengan kemampuan spiritual yang tinggi, memiliki tingkat pengetahuan yang lebih dari anggota masyarakat lain. Sehingga membuat informasi apapun yang disampaikan kepada masyarakat seolah merupakan sebuah kebenaran yang harus diyakini.

Fenomena yang kerap ditemui pada sebuah kelompok masyarakat adalah menjadikan tokoh agama mereka sebagai pedoman dalam berperilaku. Mereka dihormati karena "keahlian" mereka dalam hal spiritual. Aspek spiritual menjadi penting di tengah masyarakat teologis seperti Indonesia. Penghormatan tersebut bisa jadi diberikan sebagai wujud terimakasih atas kehadirannya di masyarakat. Dalam model kepemimpinan tradisional dijelaskan, bukan hanya seorang tokoh agama saja yang memiliki posisi tinggi dalam strata sosial. Tetapi semua anggota keluarganya memiliki "penghormatan" yang sama. Dengan diberikannya label semacam itu, keluarga seorang tokoh seolah memiliki tanggung jawab moral yang sama besarnya. Setiap tindakan yang diambil, akan selalu menjadi perhatian bagi masyarakatnya.

Pandangan yang dibangun sedemikian rupa mengenai tokoh agama, akhirnya memunculkan bias pada pemaknaan peran individu dalam sebuah masyarakat. Apabila dilihat dari sudut pandang ilmu sosial, seorang tokoh agama sama dengan masyarakat lain yang memiliki peranannya dalam sebuah masyarakat. Tetapi dengan peran seorang tokoh agama yang dijadikan sebagai percontohan, memunculkan anggapan bahwa seorang tokoh agama akan sangat minim melakukan tindakan yang bertentangan dengan norma. Dengan adanya persepsi semacam itu, membuat masyarakat merasa enggan dan tidak perlu melakukan kritisi terhadap berbagai tindakan yang dilakukan seorang tokoh agama. Kerap kali masyarakat memiliki prasangka bahwa setiap tindakan yang dilakukan oleh seorang tokoh agama, memiliki makna dibelakangnya yang tidak dapat dipahami oleh orang awam. Hal itulah yang mungkin mendasari seorang tokoh agama dapat dengan mudah memberi pengaruh yang besar pada sebuah kelompok masyarakat.

Meskipun di era modern, model kepemimpinan yang dominan di masyarakat desa adalah kepemimpinan tradisional dan karismatik. Diperlukan kebijaksanaan dari setiap orang dalam menyampaikan informasi di era digital seperti saat ini. Pasalnya, pada fenomena ini dapat dilihat bahwa seorang anggota keluarga dari tokoh agama bahkan masih ikut menyebarkan sebuah informasi hoax. Pada hasil observasi seperti yang dijelaskan di atas, memang pesan hoax tersebut menerima beberapa respon dan tidak semua langsung membenarkan informasi yang ada. Seperti terdapat pihak yang merespon dengan melakukan cross check data adalah seorang usia remaja berusia sekitar 20 tahun. Sementara terdapat pihak lain yang menganggap bahwa informasi tersebut benar adanya, dengan latar belakang usia sekitar 40 tahun dan sudah memiliki keluarga dengan Hal tersebut semakin menegaskan data bahwa, golongan dewasa atau tua menjadi penyumbang angka terbesar dalam kasus peyebaran berita hoax. Sehingga menjadi berbahaya ketika seorang tokoh masyarakat yang dihormati tidak memiliki kemampuan mencerna informasi dari media sosial dengan baik. 
Memang bukan hal mudah untuk membiasakan tidak menyebarkan sebuah informasi yang tidak jelas sumbernya. Khususnya bagi masyarkat golongan dewasa yang baru mengenal media sosial. Namun nampaknya masalah tidak sekedar pada proses adaptasi, tetapi juga kebijaksanaan dari masyarakat golongan dewasa dalam menyampaikan sebuah informasi. Bagi negara dengan kultur hirarki seperti Indonesia, masyarakat golongan dewasa harusnya lebih dapat menerima kritik dan arahan mengenai informasi yang baru mereka pahami dari golongan usia muda. Perubahan penyampaian informasi dari media cetak ke media sosial, merupakan perubahan besar yang memang harus dimaknai dengan bijak. Termasuk oleh semua kalangan tidak terkecuali tokoh masyarakat harus menyadari bahwa kini perubahan proses distribusi informasi telah bergeser. Perlu kebijaksanaan dalam penggunaan media sosial termasuk bagi mereka yang memegang peran sentral di masyarakat. Tanggung jawab serta kepercayaan dari masyarakat harus menjadi perhatian utama untuk meminimalisir munculnya konflik.

\section{Simpulan}

Media sosial saat ini sudah menjadi bagian dari aktivitas setiap individu. Media sosial tidak lagi hanya sekedar media komunikasi, namun juga menjadi media rekreasi, informasi bahkan pada sampai pada sektor konsumsi. Media sosial yang sudah masuk begitu dalam pada aspek kehidupan, perlu mendapat perhatian khusus. Mengingat begitu mudahnya mengakses informasi maka semakin tinggi pula potensi terjadinya konflik karena adanya perbedaan kepentingan. Banyak pihak yang tidak bertanggung jawab menyebarkan berbagai ujaran kebencian pada pihak lain yang dianggap menjadi lawan entah dalam bidang sosial, ekonomi bahkan politik dan agama. Proses transisi dari media cetak ke media soial inilah yang masih menjadi masalah bagi sebagian golongan yang kesulitan melakukan adaptasi. Bagi golongan usia dewasa atau yang menghabiskan masa remaja sebelum adanya media sosial, media sosial dan berbagai fiur yang ada di dalamnya masih menjadi hal baru. Kesulitan proses adaptasi ini dirasakan oleh semua kalangan usia dewasa termasuk mereka yang menjadi tokoh agama atau pemimpin masyarakat. Mengingat seorang tokoh agama layaknya pemimpin bagi umatnya, sehingga apapun yang dilakukan oleh pemimpinnya, sedikit banyak akan mempengaruhi masyarakat yang ada. Tanggung jawab untuk menjadi contoh dan panutan bagi sekitar mereka, menuntut mereka untuk selalu berusaha memberikan yang terbaik. Namun sayangnya, hal itu tidak berjalan seiring dengan kemampuan mencerna informasi dari media sosial dengan baik.

\section{Daftar Rujukan}

Arifin, Z. (2015). Kepemimpinan Kiai dalam Ideologisasi Pemikiran Santri di Pesantren-Pesantren Salafiyah Mlangi Yogyakarta. INFERENSI: Jurnal Penelitian Sosial Keagamaan, 9(2), 351-372.

Arikunto, Suharsimi. (2003). Manajemen Penelitian. Jakarta: Rineka Cipta.

Habsy, B. A. (2017). Seni memehami penelitian kuliatatif dalam bimbingan dan konseling: studi literatur. Jurnal Konseling Andi Matappa, 1(2), 90-100.

Haryanto. A.T. (2019). Kominfo Beberkan Sederet Kasus Hoax di WhatsApp. https://kominfo.go.id/content/detail/16023/kominfobeberkan-sederet-kasus-hoax-diWhatsApp/0/sorotan_media/ Diakses pada 24 Oktober 2020.

Hasan. A.M. (2019). Masalah Orangtua: Gemar Membagi Hoaks Di Medsos Dan WhatsApp. https://tirto.id/masalah-orangtua-gemar-membagi-hoaks-di-medsos-dan-WhatsApp-decZ. Diakses pada 24 Oktober 2020.

Jemadu, L. (2017). Ancaman Hoax di Indonesia Sudah Capai Tahap Serius. Diakses dari situs: http://www. suara. com/tekno/2017/05/04/141822/ancaman-hoax-di-indonesia-sudah-capai-tahap-serius. tanggal, 23. 
Jurnal Integrasi dan Harmoni Inovatif Ilmu-Ilmu Sosial (JIHI3S), 1(2), 2021, 204-213

Karim, A. G. (2009). The pesantren-based ruling elite in Sumenep in the post-new order Indonesia. Journal of Indonesian Islam, 3(1), 97-121.

Kholis, N. (2020). Kepemimpinan organisasi dalam pengurus wilayah Nahdlatul Ulama Jawa Timur: ditinjau dengan teori kepemimpinan karismatik Max Weber (Doctoral dissertation, UIN Sunan Ampel Surabaya).

Kominfo.go.id. (2020). Pengguna Internet Di Indonesia 63 Juta Orang. https://kominfo.go.id/index.php/content/detail/3415/Kominfo+\%3A+Pengguna+Internet+di+Indon esia+63+Juta+Orang/0/berita_satker. Diakses pada 24 Oktober 2020.

Moelong, J. Lexy. (2004). Metodologi Penelitian Kualitatif. Bandung, Rosda Karya.

Nasution, M. A. (2017). Hoax Sebagai Bentuk Hudud Menurut Hukum Islam. Yurisprudentia: Jurnal Hukum Ekonomi, 3(1), 16-32.

Qori, H. I. L. A. (2013). Kepemimpinan karismatik versus kepemimpinan transformasional. Jurnal Analisa, 1(2), 70-77.

Respati, S. (2017). Mengapa banyak orang mudah percaya berita "hoax". Kompas. com. https://nasional.kompas.com/read/2017/01/23/18181951/mengapa.banyak.orang.mu\%20dah.per caya.berita.hoax.?page=all

Saputri, Dian Maya. (2018). Dokumentasi sebagai Teknik Pengumpulan Data.

Setyaningrum. P.M. (2020). Penjelasan TVRI Terkait Hoaks Mimbar Agama Dan Program Belajar Dari Rumah. https://www.wartaekonomi.co.id/read281202/penjelasan-tvri-terkait-hoaks-mimbar-agama-danprogram-belajar-dari-rumah. Diakses pada 24 Oktober 2020.

Tutiasri, R. P., Kusuma, A., \& Sumardjijati, S. (2019). Perilaku Remaja dalam Penyebaran Hoax di Group WhatsApp. JURNAL ILMU KOMUNIKASI, 2(1).

Wardani. S.A. (2019). 83 Persen Pengguna Internet Indonesia Pakai WhatsApp. https://www.liputan6.com/tekno/read/4113678/83-persen-pengguna-internet-indonesia-pakaiWhatsApp. Diakses pada 24 Oktober 2020.

Creswell, J. W., Hanson, W. E., Clark Plano, V. L., \& Morales, A. (2007). Qualitative research designs: Selection and implementation. The counseling psychologist, 35(2), 236-264. 